\title{
Perspectives on a combined test of multi serum biomarkers in China: Towards screening for and diagnosing hepatocellular carcinoma at an earlier stage
}

\author{
Keming Zhang ${ }^{1}$, Peipei Song,*, Jianjun $\mathrm{Gao}^{2}$, Gaohua $\mathrm{Li}^{1}$, Xin Zhao ${ }^{1}$, Shaogeng Zhang ${ }^{1}$ \\ ${ }^{1}$ Department of Hepatobiliary Surgery, 302 Hospital of Chinese PLA, Beijing, China; \\ ${ }^{2}$ Hepato-Biliary-Pancreatic Surgery Division, Graduate School of Medicine, The University of Tokyo, Tokyo, Japan.
}

\begin{abstract}
Summary China has $50 \%$ of the worldwide hepatocellular carcinoma (HCC) cases, and the HBVrelated cases accounts for approximately $85 \%$. Over the past few decades, although a series of standardized management methods for HCC has been implemented in China, most HCC patient in China still suffered from advanced-stage disease, in consequence, reducing the opportunity of curable treatment that can be offered to achieve long-term disease-free survival for HCC patient. Accordingly, strategies including screening and diagnose $\mathrm{HCC}$ at an earlier stage are urgently needed in China. In this study, the current status, challenges, and prospects of early detection of $\mathrm{HCC}$ in China have been analyzed. The result indicated the need for using multi serum biomarkers for early HCC detection. During the past ten years, the research on the clinical usefulness of novel serum biomarkers of des- $\gamma$-carboxy-prothrombin (DCP), Dickkopf-1 (DKK1) and Midkine (MDK) in early HCC detection for Chinese patients found that the novel serum biomarker can complete the measurement of $\alpha$-fetoprotein (AFP) in the diagnosis process of $\mathrm{HCC}$, particularly for the patient with negative AFP with/or at an early stage. More large-scale, multi-center studies are expected to be performed in China to provide further evidence, and using novel and reliable serum biomarkers to complement AFP as a new trend is expected to be extensively used in clinical practice to facilitate early detection for those patients with HCC in China.
\end{abstract}

Keywords: $\alpha$-fetoprotein (AFP), des- $\gamma$-carboxyprothrombin (DCP), HCC, sensitivity, tumor marker

\section{Introduction}

Liver cancer is the fifth most common cancer and the second leading cause of cancer-related deaths worldwide, with a reported cases of 782,000 each year (1). As the most common type of liver cancer, hepatocellular carcinoma (HCC) is prevalent in Asian countries, accounting for $75-80 \%$ cases reported globally $(2,3)$. HCC is prevalent in males, the male incidence rates of the following countries or districts in Asia are over 25/100,000 (persons): mainland China $(58 / 100,000)$, Taiwan $(53 / 100,000)$, South Korea (45/100,000), Thailand (33.4/100,000), and Hong Kong

\footnotetext{
*Address correspondence to:

Dr. Peipei Song, Hepato-Biliary-Pancreatic Surgery Division, Graduate School of Medicine, The University of Tokyo, 7-3-1Hongo, Bunkyo-ku, Tokyo 113-8655, Japan.

E-mail: ppsong-tky@umin.ac.jp
}

$(29.9 / 100,000)$ of particular note is the fact that China alone accounts for $50 \%$ of HCC cases worldwide $(4,5)$. Currently, HCC become the second and third leading cause of cancer-related deaths respectively in males and in females in China (Table 1) $(6,7)$, and the HCC's incidence has increased in the past few decades caused by the high prevalence of its main etiological agents, chronic hepatitis $\mathrm{B}$ virus (HBV) infections (8-10). In fact, 93 million HBV carriers are Chinese, accounting for $2 / 3$ of such patients worldwide, and about 20 million of these people have chronic HBV infection $(11,12)$.

Evidence has shown that surgical resection and liver transplantation may offer the best opportunity for treating $\mathrm{HCC}$ yet are only available to early-detected patients (13-16). The normal overall 5-year survival rate is $40 \%$, but with a liver resection to treat early $\mathrm{HCC}$, the 5-year survival rate rise to $60-70 \%(17,18)$. Over the past few decades, a series of standardized management methods for HCC has been implemented 
Table 1.The current status to screen for and diagnose HCC in China

\begin{tabular}{|c|c|}
\hline Items & Current status in China \\
\hline Prevalence & $\begin{array}{l}\text { The second most common cancer in urban areas and most common in rural areas; with an overall } \\
\text { prevalence rate of } 26-32 / 10,000 \text {, even up to } 70-80 / 10,000 \text { in some areas }(5,11)\end{array}$ \\
\hline Mortality & $\begin{array}{l}\text { The second leading cause of cancer-related deaths in males and the third leading cause of cancer- } \\
\text { related deaths in females; with a total mortality rate of } 26.26 / 100,000(11)\end{array}$ \\
\hline Etiological factors & $\begin{array}{l}85 \% \text { of patients with } \mathrm{HBV} \text { infection, } 10 \% \text { of patients with HCVinfection, and a small minority } \\
\text { involve } \mathrm{HBV} \text { and } \mathrm{HCV}(8,9)\end{array}$ \\
\hline Major at-risk population & $\begin{array}{l}\text { People with HBV infection; } 93 \text { million HBV carriers, } 20 \text { millionof these with chronic HBV } \\
\text { Infection }(11,12)\end{array}$ \\
\hline Screening and surveillance & $\begin{array}{l}\text { No government-funded screening and surveillance program for } \mathrm{HCC} \text { high-risk population } \\
\text { screening and surveillance }(10)\end{array}$ \\
\hline Screening and Diagnostic algorithm & $\begin{array}{l}\text { The test of ultrasonography and AFP every } 6 \text { months for the population ages } 35-40 \text { at risk for } \\
\text { developing HCC ( } 6 \text { ) }\end{array}$ \\
\hline Treatment algorithm & Comprehensive therapy predominantly in the form of surgery ( 7$)$ \\
\hline Early detection & Most patients with HCC present with advanced-stage disease (10) \\
\hline
\end{tabular}

by China Government, and the Expert Consensus on the Treatment Standards for Hepatic Carcinoma, the Chinese Guidelines on HCC, was drafted in 2009 (19). Currently, standard treatment for HCC in China is comprehensive therapy predominantly in the form of surgery $(7,20)$. As clinical techniques have developed in China, new techniques have also become available, such as laparoscopic surgery and minimally invasive robotic surgery. However, most HCC patient in China still suffered from advanced-stage disease (10), thus reducing the chance of curable treatment. Accordingly, strategies to screen for and diagnose $\mathrm{HCC}$ at an earlier stage are urgently needed in China when curable interventions can be offered to achieve long-term disease-free survival for HCC patient (21).

\section{The current strategies to screen for and diagnose HCC in China}

\subsection{Screening high-risk population for developing $H C C$}

Evidence showed that screening high-risk HBV- or HCV-related chronic liver diseases population may improve the rate of early HCC detection and curative treatment. It has been found by a systematic literature review involving over three thousand papers included in PubMed database between 2001 and 2011 (22), and it has also been shown by several cohort studies (23-25).

Unlike in the USA, European countries, and other Asian countries such as Japan where HCV is the most significant etiological factor for developing HCC (26), the HBV-related cases accounts for approximately $85 \%$ while only $10 \%$ are HCV-related and a small minority involve HBV and HCV in China $(8,9)$. Thus, people with $\mathrm{HBV}$ are the largest risk population for developing HCC in China.
Globally, many guidelines for HCC treatment recommend HCC screening and surveillance, including the guidelines established by the American Association for the Study of Liver Disease (AASLD) (27), the National Comprehensive Cancer Network (NCCN) (28), and the Asian Pacific Association for the Study of the Liver (APASL) (29). In Asia, Japan and South Korea have implemented their own nationwide screening and surveillance program for the HCC high-risk population. In Japan, as early as 2002, the Japanese Ministry of Health, Labor, and Welfare started a national 5-year program to screen for HCV and HBV infection among people over 40 years of age, given the high prevalence of HCV infection in this age group (30). With the support of this program, 9 million people had been screened until the end of 2006, 112,000 scanning objects were found infected HCV and 110,000 were found infected HBV (31). Since most high-risk patients were closely followed, more than $60 \%$ of cases had detected HCC nodules in the early stage in Japan $(32,33)$.

Similarly, a screening and surveillance program has also established in Taiwan. The program focuses on screening patients with cirrhosis every 3-6 months and patients with no cirrhosis every 6-12 months $(10,34)$. However, there is no such program funded by government for HCC high-risk population screening in China, including Hong Kong (10). As a result, a well thought-out strategy for screening high-risk populations with HBV-related chronic liver disease is urgently needed in China to enhance the early detection of HCC.

\subsection{Serum biomarkers for screening and diagnosis of $\mathrm{HCC}$}

Screening and diagnosis tools should have an acceptable accuracy and cost. In general, imaging tools have been 
widely used in the USA and European countries, while serum biomarkers are widely used in HCC screening and diagnosis in Asia. Diagnostic imaging techniques include ultrasonography, computed tomography (CT), and magnetic resonance imaging (MRI). According to a systematic review, ultrasonography has a $60 \%$ sensitivity and a $97 \%$ specificity, CT has a $68 \%$ sensitivity and a $93 \%$ specificity, and MRI has a $81 \%$ sensitivity and a $85 \%$ specificity (35). Ultrasound is the most common imaging tool used in the screening process for HCC thanks to is the features such as simple, inexpensive, non-invasive, and allows realtime observation. However, a successful ultrasounddetection relies on the expertise of the physician, the available of ultrasound equipment, and the echo texture of the liver. So the actual sensitivity and specificity of ultrasound-detection is difficult to evaluate due to the lack of standard in China $(36,37)$.

Serum biomarkers are striking prospective alternative tools for screening and early diagnosis of HCC thanks to the non-invasive, objective, and reproducible assessments they would enabled (38). According to the Chinese Guidelines on HCC, ultrasonography and $\alpha$-fetoprotein (AFP) measurement are recommended to be performed every 6 months for the people ages between 35 and 40 at risk for developing HCC ( 6 ). Currently, the serum biomarker AFP is considered as a useful and practicable tool for the screening and early diagnosis of HCC in China. The clinical usefulness of AFP in China has been ascertained by a trial that with a randomized control in 2004 which involved 18,816 Chinese patients aged between 35 and 59 with HBV infection or a history of chronic hepatitis (39). However, the sensitivity of AFP is unsatisfactory $(25-65 \%)$ at the commonly used cut-off $(20 \mathrm{ng} / \mathrm{mL})$, especially in the detection of early-stage $\operatorname{HCC}(40,41)$, up to $50 \%$ of HCC patients have an AFP level below 20 $\mathrm{ng} / \mathrm{mL}$. Elevated levels of AFP could also be found in non-malignant chronic liver disease patients, including $15-58 \%$ with chronic hepatitis and $11-47 \%$ with liver cirrhosis (42-44).

Besides, there are many diagnostic difficulties in clinical practice, such as cases with high AFP level, but no space occupying lesion by imaging finding, cases with negative AFP, less than $1 \mathrm{~cm}$ or no HCC featured lesion by imaging finding (7). Thus, AFP cannot be used as a sole tool to screening and diagnose HCC. The novel and dependable serum biomarkers to complement AFP are urgently needed to be discovered in order to improve the clinical outcomes.

\section{The future perspective on using multi serum biomarkers in early HCC detection in China}

\subsection{The combined test of AFP, AFP-L3, and DCP}

Besides AFP, there are two other serum biomarkers
- lens culinaris agglutinin-reactive fraction of AFP (AFP-L3), and des- $\gamma$-carboxyprothrombin (DCP, also known as prothrombin induced by vitamin $\mathrm{K}$ absenceII, PIVKA-II) - that have been studied worldwide to explore for clinical usefulness in HCC screening and diagnosis, and has been used in some countries (45-48). According to HCC Guidelines in Japan, ultrasonography and measurement of AFP, AFP-L3, or DCP should be performed every 3-4 months in the highest-risk group (HBV- or HCV-related liver cirrhosis patients) and every 6-month in the high-risk group (patients with HBV- or HCV-related chronic liver disease or liver cirrhosis due to other causes) $(49,50)$. Currently, AFP, AFP-L3, and DCP are used widely and routinely as a tool for screening HCC in Japan, and these tests are covered by Japan's national health insurance as the serum biomarkers to screen for HCC in clinical settings.

Worldwide, a number of researches have carried out at DCP. In 1984, Liebman et al.(51) first reported DCP in the plasma of $90 \%$ of patients with HCC. Since then, substantial evidence has been assembled through numerous clinical trials, and studies have demonstrated the clinical usefulness of serum DCP levels to screen for and diagnose patients with $\operatorname{HCC}(48,52,53)$. Multiple reports have found that the combined testing of DCP and AFP have a sensitivity of $47.5-94.0 \%$ and specificity of 53.3-98.5\% in HCC early detection (Table 2) $(45,46,48,53-67)$.

Meanwhile, many researchers recommend that DCP could also be used in assessing the progression of $\mathrm{HCC}$, including serving as an $\mathrm{HCC}$ recurrence indicator after curative therapy, a good predictor of the vascular invasion presence and could be used to select liver transplants' recipients, and could facilitate the research of new chemotherapeutic strategies for treating HCC (68-74). However, currently, DCP is approved in Japan, Korea and Indonesia (75), yet has not been approved in China until now.

\subsection{Evidence for exploration of using DCP in early $\mathrm{HCC}$ detection in China}

Evidence has shown that the test that combine DCP and AFP could achieve a better sensitivity and specificity in HCC early detection, and the testing of DCP has been widely used for many HCV-related HCC cases, such as in Japan. But in China, 85\% of HCC cases have HBV infection. So, is DCP applicable as a screening and diagnostic tool in China? What about its sensitivity and specificity in Chinese HCC cases? Furthermore, what is its clinical usefulness in assessing HCC progression? According to evidence-based medicine (EBM), systematic evaluation needs to be performed to assess the screening and diagnostic value of DCP in Chinese patients with HCC.

In China, such a study was conducted in 2002 to 
Table 2.The exploration of clinical usefulness of using serum biomarker DCP to complement AFP in HCC early detection*

\begin{tabular}{|c|c|c|c|c|c|}
\hline Marker & Cut-off value & Sensitivity $^{\mathrm{a}}$ & Specificity $^{\mathrm{a}}$ & $\mathrm{PPV}^{a}$ & $\mathrm{NPV}^{\mathrm{a}}$ \\
\hline $\mathrm{DCP}+\mathrm{AFP}(54)$ & $8 \mathrm{mAU} / \mathrm{mL}, 20 \mathrm{ng} / \mathrm{mL}$ & $90.0 \%(90 / 100)$ & $N$ & $N$ & $N$ \\
\hline $\mathrm{DCP}+\mathrm{AFP}(55)$ & $16 \mathrm{mAU} / \mathrm{mL}, 20 \mathrm{ng} / \mathrm{mL}$ & $87.3 \%(55 / 63)$ & $84.0 \%(158 / 188)$ & $64.7 \%(55 / 85)$ & $95.2 \%(158 / 166)$ \\
\hline $\mathrm{DCP}+\operatorname{AFP}(56)$ & $40 \mathrm{mAU} / \mathrm{mL}, 20 \mathrm{ng} / \mathrm{mL}$ & $83.5 \%(76 / 91)$ & $N$ & $N$ & $N$ \\
\hline $\mathrm{DCP}+\operatorname{AFP}(57)$ & $40 \mathrm{mAU} / \mathrm{mL}, 20 \mathrm{ng} / \mathrm{mL}$ & $86.7 \%(52 / 60)$ & $N$ & $N$ & $N$ \\
\hline $\mathrm{DCP}+\mathrm{AFP}(58)$ & $40 \mathrm{mAU} / \mathrm{mL}, 20 \mathrm{ng} / \mathrm{mL}$ & $78.3 \%(94 / 120)$ & $58.9 \%(53 / 90)$ & $71.8 \%(94 / 131)$ & $67.1 \%(53 / 79)$ \\
\hline $\mathrm{DCP}+\operatorname{AFP}(62)$ & $40 \mathrm{mAU} / \mathrm{mL}, 20 \mathrm{ng} / \mathrm{mL}$ & $83.6 \%(51 / 61)$ & $68.2 \%(45 / 66)$ & $70.8 \%(51 / 72)$ & $81.8 \%(45 / 55)$ \\
\hline $\mathrm{DCP}+\mathrm{AFP}(63)$ & $40 \mathrm{mAU} / \mathrm{mL}, 20 \mathrm{ng} / \mathrm{mL}$ & $83.3 \%(204 / 245)$ & $77.2 \%(206 / 267)$ & $77.0 \%(204 / 265)$ & $83.4 \%(206 / 247)$ \\
\hline $\mathrm{DCP}+\mathrm{AFP}(59)$ & $40 \mathrm{mAU} / \mathrm{mL}, 200 \mathrm{ng} / \mathrm{mL}$ & $78.3 \%(83 / 106)$ & $N$ & $N$ & $N$ \\
\hline $\mathrm{DCP}+\mathrm{AFP}(45)$ & $80 \mathrm{mAU} / \mathrm{mL}, 40 \mathrm{ng} / \mathrm{mL}$ & $65.5 \%(19 / 29)$ & $84.5 \%(596 / 705)$ & $14.8 \%(19 / 128)$ & $98.3 \%(596 / 606)$ \\
\hline $\mathrm{DCP}+\mathrm{AFP}(64)$ & $90 \mathrm{mAU} / \mathrm{mL}, 45 \mathrm{ng} / \mathrm{mL}$ & $84.4 \%(130 / 154)$ & $N$ & $N$ & $N$ \\
\hline $\mathrm{DCP}+\mathrm{AFP}(60)$ & $100 \mathrm{mAU} / \mathrm{mL}, 100 \mathrm{ng} / \mathrm{mL}$ & $72.4 \%(55 / 76)$ & $N$ & $N$ & $N$ \\
\hline $\mathrm{DCP}+\operatorname{AFP}(60)$ & $100 \mathrm{mAU} / \mathrm{mL}, 300 \mathrm{ng} / \mathrm{mL}$ & $63.2 \%(48 / 76)$ & $N$ & $N$ & $N$ \\
\hline $\mathrm{DCP}+\operatorname{AFP}(48)$ & $150 \mathrm{mAU} / \mathrm{mL}, 20 \mathrm{ng} / \mathrm{mL}$ & $86 \%(-/-)^{\mathrm{b}}$ & $63 \%(-/-)^{b}$ & $N$ & $N$ \\
\hline $\mathrm{DCP}+\operatorname{AFP}(48)$ & $619 \mathrm{mAU} / \mathrm{mL}, 27 \mathrm{ng} / \mathrm{mL}$ & $74 \%(-/-)^{\mathrm{b}}$ & $87 \%(-/-)^{b}$ & $N$ & $N$ \\
\hline $\mathrm{DCP}+\operatorname{AFP}(64)$ & $0.8 \mathrm{ng} / \mathrm{mL}, 45 \mathrm{ng} / \mathrm{mL}$ & $88.3 \%(136 / 154)$ & $N$ & $N$ & $N$ \\
\hline $\mathrm{DCP}+\mathrm{AFP}(53)$ & $20.24 \mathrm{ng} / \mathrm{mL}, 15 \mathrm{ng} / \mathrm{mL}$ & $94.0 \%(47 / 50)$ & $80.5 \%(33 / 41)$ & $85.5 \%(47 / 55)$ & $91.7 \%(33 / 36)$ \\
\hline $\mathrm{DCP}+\operatorname{AFP}(65)$ & $0.1 \mu \mathrm{g} / \mathrm{mL}, 20 \mathrm{ng} / \mathrm{mL}$ & $92.9 \%(65 / 70)$ & $53.3 \%(24 / 45)$ & $75.6 \%(65 / 86)$ & $82.8 \%(24 / 29)$ \\
\hline $\mathrm{DCP}+\mathrm{AFP}(65)$ & $0.1 \mathrm{mg} / \mathrm{mL}, 400 \mathrm{ng} / \mathrm{mL}$ & $85.7 \%(60 / 70)$ & $82.2 \%(37 / 45)$ & $88.2 \%(60 / 68)$ & $78.7 \%(37 / 47)$ \\
\hline $\mathrm{DCP}+\mathrm{AFP}(66)$ & $40 \mathrm{mAU} / \mathrm{ml}, 20 \mathrm{ng} / \mathrm{ml}$ & $78.3 \%(47 / 60)$ & $56.7 \%(17 / 30)$ & $N$ & $N$ \\
\hline $\mathrm{DCP}+\operatorname{AFP}(54)$ & $8 \mathrm{mAU} / \mathrm{mL}, 20 \mathrm{ng} / \mathrm{mL}$ & $66.7 \%(18 / 27)$ & $N$ & $N$ & $N$ \\
\hline $\mathrm{DCP}+\operatorname{AFP}(55)$ & $16 \mathrm{mAU} / \mathrm{mL}, 20 \mathrm{ng} / \mathrm{mL}$ & $82.9 \%(29 / 35)$ & $84.0 \%(158 / 188)$ & $49.2 \%(29 / 59)$ & $96.3 \%(158 / 164)$ \\
\hline $\mathrm{DCP}+\operatorname{AFP}(58)$ & $40 \mathrm{mAU} / \mathrm{mL}, 20 \mathrm{ng} / \mathrm{mL}$ & $59.4 \%(-/-) b$ & $58.9 \%(53 / 90)$ & $N$ & $N$ \\
\hline $\mathrm{DCP}+\operatorname{AFP}(48)$ & $150 \mathrm{mAU} / \mathrm{mL}, 20 \mathrm{ng} / \mathrm{mL}$ & $78 \%(-/-)^{\mathrm{b}}$ & $62 \%(-/-)^{b}$ & $N$ & $N$ \\
\hline $\mathrm{DCP}+\mathrm{AFP}(48)$ & $598 \mathrm{mAU} / \mathrm{mL}, 11 \mathrm{ng} / \mathrm{mL}$ & $70 \%(-/-)^{b}$ & $80 \%(-/-)^{\mathrm{b}}$ & $N$ & $N$ \\
\hline $\mathrm{DCP}+\mathrm{AFP}(55)$ & $16 \mathrm{mAU} / \mathrm{mL}, 20 \mathrm{ng} / \mathrm{mL}$ & $61.5 \%(8 / 13)$ & $84.0 \%(158 / 188)$ & $21.1 \%(8 / 38)$ & $96.9 \%(158 / 163)$ \\
\hline $\mathrm{DCP}+\operatorname{AFP}(56)$ & $40 \mathrm{mAU} / \mathrm{mL}, 20 \mathrm{ng} / \mathrm{mL}$ & $83.7 \%(36 / 43)$ & $N$ & $N$ & $N$ \\
\hline $\mathrm{DCP}+\mathrm{AFP}(67)$ & $40 \mathrm{mAU} / \mathrm{mL}, 200 \mathrm{ng} / \mathrm{mL}$ & $47.5 \%(29 / 61)$ & $98.5 \%(132 / 134)$ & $93.5 \%(29 / 31)$ & $80.5 \%(132 / 164)$ \\
\hline $\mathrm{DCP}+\mathrm{AFP}-\mathrm{L} 3(61)$ & $40 \mathrm{mAU} / \mathrm{mL}, 10 \%$ & $41.7 \%(15 / 36)$ & $89.8 \%(44 / 49)$ & $75.0 \%(15 / 20)$ & $67.7 \%(44 / 65)$ \\
\hline $\mathrm{DCP}+\mathrm{AFP}-\mathrm{L} 3(46)$ & $40 \mathrm{mAU} / \mathrm{mL}, 10 \%$ & $66.7 \%(14 / 21)$ & $89.5 \%(51 / 57)$ & $70.0 \%(14 / 20)$ & $87.9 \%(51 / 58)$ \\
\hline $\mathrm{DCP}+\mathrm{AFP}-\mathrm{L} 3$ (67) & $40 \mathrm{mAU} / \mathrm{mL}, 10 \%$ & $54.1 \%(33 / 61)$ & $97.8 \%(131 / 134)$ & $91.7 \%(33 / 36)$ & $82.4 \%(131 / 159)$ \\
\hline
\end{tabular}

* In all studies indicated, patients with chronic hepatitis and/or liver cirrhosis were designated as the comparative non-HCC patient group. ${ }^{\text {a }}$ Sensitivity $=$ True positive $(\mathrm{TP}) /(\mathrm{TP}+$ Falsenegative $(\mathrm{FN}))$, Specificity $=$ True negative $(\mathrm{TN}) /(\mathrm{TN}+$ False positive $(\mathrm{FP}))$, Positive predictive value $(\mathrm{PPV})=\mathrm{TP} / \mathrm{TP}+\mathrm{FP}$, Negative predictive value $(\mathrm{NPV})=\mathrm{TN} / \mathrm{TN}+\mathrm{FN}$. ${ }^{\mathrm{b}}$ The patient distribution was not noted. $N$, Not noted or not investigated.

determine DCP and AFP levels in 60 patients with HCC and 30 patients with cirrhosis but no HCC (66), results showed that the combined testing of DCP and AFP could achieve a sensitivity of $78.3 \%$, which is higher than that of DCP alone (51.7\%) and AFP alone (56.7\%). Another study to assess the clinical usefulness of DCP involving 120 Chinese patients with HCC and 90 patients with cirrhosis was reported in 2003 (58), and results also showed that the combined tests of DCP and AFP had a sensitivity of $78.3 \%$, which is higher than that of DCP (53.3\%) and AFP alone (58.3\%).

Moreover, a large-scale, multi-center study of DCP's usefulness in early HCC detection was also launched in Chongqing, Beijing, and Tianjin of China in 2012 (11). As part of the study, the test was conducted in one of the centers - the Southwest Hospital, Third Military Medical University in Chongqing - involving 336 patients with HCC $(80 \%$ have HBV infection) and 252 patients with liver diseases other than HCC. Results showed that there is no significant correlation between serum levels of DCP and AFP $\left(R^{2}=0.0179\right)$; DCP had a total sensitivity of $74 \%$ while a combination of DCP and AFP had a sensitivity of $84 \%$, which is higher than either DCP or AFP alone $(7,11)$. Besides, DCP resulted in a specificity of $56 \%$ with a cut-off value of 40 $\mathrm{mAU} / \mathrm{mL}$ and $94 \%$ with a cut-off value of $100 \mathrm{mAU} /$ $\mathrm{mL}(32)$.

These studies found that the combined tests of DCP and AFP could improve sensitivity for detecting Chinese HCC cases, thus suggesting that DCP is a useful serum biomarker in Chinese patients for HCC screening and early diagnosis. Such evidence provides a better perspective for using DCP in HCC early detection in China. However, more large-scale, multicenter studies are expected to be performed in China to provide further evidence of the clinical usefulness of serum biomarker DCP in early HCC detection, especially with long-term surveillance and follow-up to provide strong data-support and verification.

\subsection{Research advances in other serum biomarkers for early HCC detection in China}

In recent years, there are also many studies on the clinical usefulness of other serum biomarkers in early HCC detection, including Golgi protein-73 (GP73), glypican-3 (GPC3), gamma-glutamyltransferase (GGTII), and so on. Most recently, research on 
Dickkopf-1 (DKK1) and Midkine (MDK) as diagnostic serum biomarkers has raised concern in China.

Serum DKK1 as a biomarker in HCC diagnosis Published in 2012, a large-scale, multi-centre study assessed serum DKK1 for HCC diagnosis in 1,284 participants (831 in the test cohort and 453 in the validation cohort) in China $(76,77)$. Results showed that serum's levels of DKK1 were significantly higher in HCC patients than in all controls; serum DKK1 had greater AUC, sensitivity, and specificity values than did AFP in patients with HCC compared with chronic HBV infection and cirrhosis controls; DKK1 maintained high diagnostic accuracy for AFP negative HCC patients, including early-stage HCC patients; raised concentrations of DKK1 in serum could distinguish HCC from chronic HBV infection and cirrhosis; measurement of DKK1 and AFP together improved diagnostic accuracy against HCC versus all controls compared with any test alone.

Serum MDK as a biomarker in HCC diagnosis Published in 2013, a study that involved three independent cohorts with a total of 933 participants including $388 \mathrm{HCC}$ cases and 545 different controls enrolled from different medical centers (78). Results showed that MDK levels were significantly elevated in HCC tissues as well as serum samples; serum MDK for HCC diagnosis showed an obviously higher sensitivity compared with AFP $(86.9 \%$ vs.51.9\%) with similar specificities ( $83.9 \%$ vs.86.3\%); even in very early-stage HCC, the sensitivity of MDK is significant higher than AFP ( $80 \%$ vs. $40 \%)$; in those AFP-negative HCC cases, the sensitivity could reach as high as $89.2 \%$; and serum MDK level was significantly decreased in HCC patients after curative resection and re-elevated when tumor relapsed.

Both of the two studies suggested that the novel serum biomarkers of DKK1 and MDK can complete the measurement of AFP in the diagnosis process of HCC, particularly for those negative AFP patients and/or at an early stage. However, these studies were small-scale. According to the guidelines on phases of evaluating an early detection biomarker for cancer developed by the National Cancer Institute's Early Detection Research Network (79), further validation using larger cohort of serum HCC samples with hepatitis B and hepatitis C infectious liver disease, nonalcoholic fatty liver disease (NAFLD), and alcohol-induced liver disease (ALD) from multiple centers in a prospective, randomized controlled trial is needed to provide further evidence in China.

In conclusion, research and exploration for using multi serum biomarkers in early HCC detection has raised concern in China. Using novel and reliable serum biomarkers to complement AFP as a new trend is expected to be extensively used in China to facilitate screening for and diagnosing $\mathrm{HCC}$ at an earlier stage and improve clinical outcomes.

\section{References}

1. World Health Organization. GLOBOCAN 2012: Estimated Cancer Incidence, Mortality and Prevalence Worldwide in 2012. http://globocan.iarc.fr/Pages/fact sheets_cancer:aspx (accessed May 20, 2014)

2. Jemal A, Bray F, Center MM, Ferlay J, Ward E, Forman D. Global cancer statistics. CA Cancer J Clin. 2011; 61:6990 .

3. Venook AP, Papandreou C, Furuse J, de Guevara LL. The incidence and epidemiology of hepatocellular carcinoma: a global and regional perspective. The oncologist. 2010; 15 Suppl 4:5-13.

4. Asia-Pacific Working Party on Prevention of Hepatocellular C. Prevention of hepatocellular carcinoma in the Asia-Pacific region: Consensus statements. Journal of gastroenterology and hepatology. 2010; 25:657-663.

5. Yuen MF, Hou JL, Chutaputti A, Asia Pacific Working Party on Prevention of Hepatocellular C. Hepatocellular carcinoma in the Asia pacific region. Journal of gastroenterology and hepatology. 2009; 24:346-353.

6. Chinese Anti-Cancer Association Society of Liver Cancer, Chinese Society of Clinical Oncology, Chinese Society of Hepatology Liver Cancer Study Group. The expert consensus on the treatment standards for hepatocellular carcinoma. Digestive Disease and Endoscopy. 2009; 3:40-51.

7. Song P, Feng X, Zhang K, Song T, Ma K, Kokudo N, Dong J, Tang W. Perspectives on using des- $\gamma-$ carboxyprothrombin (DCP) as a serum biomarker: Facilitating early detection of hepatocellular carcinoma in China. Hepatobiliary Surg Nutr. 2013; 2:227-231.

8. Tanaka M, Katayama F, Kato H, Tanaka H, Wang J, Qiao YL, Inoue $\mathrm{M}$. Hepatitis $\mathrm{B}$ and $\mathrm{C}$ virus infection and hepatocellular carcinoma in China: A review of epidemiology and control measures. J Epidemiol. 2011; 21:401-416.

9. Yuen MF, Hou JL, Chutaputti A. Hepatocellular carcinoma in the Asia pacific region. J Gastroenterol Hepatol. 2009; 24:346-353.

10. Kudo M, Han KH, Kokudo N, Cheng AL, Choi BI, Furuse J, Izumi N, Park JW, Poon RT, Sakamoto M. Liver Cancer Working Group report. Jpn J Clin Oncol. 2010; 40 Suppl 1:i19-27.

11. Song P, Feng X, Zhang K, Song T, Ma K, Kokudo N, Dong J, Yao L, Tang W. Screening for and surveillance of high-risk patients with HBV-related chronic liver disease: promoting the early detection of hepatocellular carcinoma in China. Biosci Trends. 2013; 7:1-6.

12. Zhang C, Zhong Y, Guo L. Strategies to prevent hepatitis $B$ virus infection in China: immunization, screening, and standard medical practices. Biosci Trends. 2013; 7:7-12.

13. Qin LX, Tang ZY. Recent progress in predictive biomarkers for metastatic recurrence of human hepatocellular carcinoma: A review of the literature. J Cancer Res Clin Oncol. 2004; 130:497-513.

14. Ji J, Shi J, Budhu A, et al. MicroRNA expression, survival, and response to interferon in liver cancer. N Engl J Med. 2009; 361:1437-1447.

15. Llovet JM, Di Bisceglie AM, Bruix J, Kramer BS, Lencioni R, Zhu AX, Sherman M, Schwartz M, Lotze M, Talwalkar J, Gores GJ. Design and endpoints of clinical trials in hepatocellular carcinoma. J Natl Cancer Inst. 2008; 100:698-711. 
16. Akamatsu N, Sugawara Y. Primary biliary cirrhosis and liver transplantation. Intractable Rare Dis Res 1: 66$80,2012$.

17. Gao JJ, Song PP, Tamura S, Hasegawa K, Sugawara Y, Kokudo N, Uchida K, Orii R, Qi FH, Dong JH, Tang W. Standardization of perioperative management on hepatobiliary-pancreatic surgery. Drug Discov Ther. 2012; 6:108-111

18. Llovet JM, Burroughs A, Bruix J. Hepatocellular carcinoma. Lancet. 2003; 362:1907-1917.

19. Song P, Tang W, Tamura S, Hasegawa K, Sugawara Y, Dong J, Kokudo N. The management of hepatocellular carcinoma in Asia: A guideline combining quantitative and qualitative evaluation. Biosci Trends. 2010; 4:283287.

20. Feng XB, Zheng SG, Xia F, Ma KS, Wang SG, Bie P, Dong JH. Classification and management of hepatolithiasis: A high-volume, single-center's experience. Intractable Rare Dis Res 1: 151-156, 2012.

21. Forner A, Llovet JM, Bruix J. Hepatocellular carcinoma. Lancet. 2012; 379:1245-1255.

22. Song P, Tobe RG, Inagaki Y, Kokudo N, Hasegawa K, Sugawara Y, Tang W. The management of hepatocellular carcinoma around the world: A comparison of guidelines from 2001 to 2011. Liver Int. 2012; 32:1053-1063.

23. Yuen MF, Cheng CC, Lauder IJ, Lam SK, Ooi CG, Lai CL. Early detection of hepatocellular carcinoma increases the chance of treatment: Hong Kong experience. Hepatology. 2000; 31:330-335.

24. Bolondi L, Sofia S, Siringo S, Gaiani S, Casali A, Zironi G, Piscaglia F, Gramantieri L, Zanetti M, Sherman M. Surveillance programme of cirrhotic patients for early diagnosis and treatment of hepatocellular carcinoma: a cost effectiveness analysis. Gut. 2001; 48:251-259.

25. Danta M, Barnes E, Dusheiko G. The surveillance and diagnosis of hepatocellular carcinoma. Eur J Gastroenterol Hepatol. 2005; 17:491-496.

26. Byam J, Renz J, Millis JM. Liver transplantation for hepatocellular carcinoma. Hepatobiliary Surg Nutr. 2013; 2: 22-30.

27. Bruix J, Sherman M. Management of hepatocellular carcinoma. Hepatology. 2005; 42:1208-1236.

28. Benson AB, 3rd, Abrams TA, Ben-Josef E, et al. NCCN clinical practice guidelines in oncology: hepatobiliary cancers. J Natl Compr Canc Netw. 2009; 7:350-391.

29. Omata M, Lesmana LA, Tateishi R, et al. Asian Pacific Association for the Study of the Liver consensus recommendations on hepatocellular carcinoma. Hepatol Int. 2010; 4:439-474.

30. Yoshizawa H, Tanaka J: A national project for the management of viral hepatitis toward prevention of hepatocellular carcinoma in Japan; in Morrissey RF (ed): International Kilmer Conference Proceedings. Laval, Polyscience Publications, vol 8, pp 247-264, 2004.

31. Yoshizawa H, Tanaka J, Miyakawa Y. National prevention of hepatocellular carcinoma in Japan based on epidemiology of hepatitis $\mathrm{C}$ virus infection in the general population. Intervirology. 2006; 49:7-17.

32. Song PP, Gao JJ, Inagaki Y, Kokudo N, Hasegawa K, Sugawara Y, Tang W. Biomarkers: Evaluation of screening for and early diagnosis of hepatocellular carcinoma in Japan and China. Liver Cancer. 2013;2: 3139.

33. Izumi N. Diagnostic and treatment algorithm of the Japanese society of hepatology: a consensus-based practice guideline. Oncology. 2010; 78 Suppl 1:78-86.

34. Chen TH, Chen CJ, Yen MF, Lu SN, Sun CA, Huang GT, Yang PM, Lee HS, Duffy SW. Ultrasound screening and risk factors for death from hepatocellular carcinoma in a high risk group in Taiwan. Int J Cancer. 2002; 98:257261.

35. Colli A, Fraquelli M, Casazza G, Massironi S, Colucci A, Conte D, Duca P. Accuracy of ultrasonography, spiral CT, magnetic resonance, and alpha-fetoprotein in diagnosing hepatocellular carcinoma: a systematic review. Am J Gastroenterol. 2006; 101:513-523.

36. Aghoram R, Cai P, Dickinson JA. Alpha-foetoprotein and/or liver ultrasonography for screening of hepatocellular carcinoma in patients with chronic hepatitis B. Cochrane Database Syst Rev. 2012; 9:CD002799.

37. Amarapurkar D, Han KH, Chan HL, Ueno Y. Application of surveillance programs for hepatocellular carcinoma in the Asia-Pacific Region. J Gastroenterol Hepatol. 2009; 24:955-961.

38. Forner A, Bruix J. Biomarkers for early diagnosis of hepatocellular carcinoma. Lancet Oncol. 2012; 13:750751.

39. Zhang BH, Yang BH, Tang ZY. Randomized controlled trial of screening for hepatocellular carcinoma. J Cancer Res Clin Oncol. 2004; 130:417-422.

40. Farinati F, Marino D, De Giorgio M, Baldan A, Cantarini M, Cursaro C, Rapaccini G, Del Poggio P, Di Nolfo MA, Benvegnu L, Zoli M, Borzio F, Bernardi M, Trevisani F. Diagnostic and prognostic role of alpha-fetoprotein in hepatocellular carcinoma: both or neither? Am J Gastroenterol. 2006; 101:524-532.

41. El-Serag HB, Marrero JA, Rudolph L, Reddy KR. Diagnosis and treatment of hepatocellular carcinoma. Gastroenterology. 2008; 134:1752-1763.

42. Daniele B, Bencivenga A, Megna AS, Tinessa V. Alpha-fetoprotein and ultrasonography screening for hepatocellular carcinoma. Gastroenterology. 2004; 127:S108-112.

43. Taketa K. Alpha-fetoprotein: Reevaluation in hepatology. Hepatology. 1990; 12:1420-1432.

44. Johnson PJ. The role of serum alpha-fetoprotein estimation in the diagnosis and management of hepatocellular carcinoma. Clin Liver Dis. 2001; 5:145159.

45. Ishii M, Gama H, Chida N, Ueno Y, Shinzawa H, Takagi T, Toyota T, Takahashi T, Kasukawa R. Simultaneous measurements of serum alpha-fetoprotein and protein induced by vitamin $\mathrm{K}$ absence for detecting hepatocellular carcinoma. South Tohoku District Study Group. Am J Gastroenterol. 2000; 95:1036-1040.

46. Shimauchi Y, Tanaka M, Kuromatsu R, Ogata R, Tateishi Y, Itano S, Ono N, Yutani S, Nagamatsu H, Matsugaki S, Yamasaki S, Tanikawa K, Sata M. A simultaneous monitoring of Lens culinaris agglutinin A-reactive alphafetoprotein and des-gamma-carboxy prothrombin as an early diagnosis of hepatocellular carcinoma in the follow-up of cirrhotic patients. Oncol Rep. 2000; 7:249256.

47. Durazo FA, Blatt LM, Corey WG, Lin JH, Han S, Saab S, Busuttil RW, Tong MJ. Des-gamma-carboxyprothrombin, alpha-fetoprotein and AFP-L3 in patients with chronic hepatitis, cirrhosis and hepatocellular carcinoma. J Gastroenterol Hepatol. 2008; 23:1541-1548.

48. Marrero JA, Feng Z, Wang Y, et al. Alpha-fetoprotein, 
des-gamma carboxyprothrombin, and lectin-bound alpha-fetoprotein in early hepatocellular carcinoma. Gastroenterology. 2009; 137:110-118.

49. Clinical Practice Guidelines for Hepatocellular Carcinoma - The Japan Society of Hepatology 2009 update. Hepatol Res. 2010; 40 Suppl 1:2-144.

50. Makuuchi M, Kokudo N, Arii S, Futagawa S, Kaneko S, Kawasaki S, Matsuyama Y, Okazaki M, Okita K, Omata M, Saida Y, Takayama T, Yamaoka Y. Development of evidence-based clinical guidelines for the diagnosis and treatment of hepatocellular carcinoma in Japan. Hepatol Res. 2008; 38:37-51.

51. Liebman HA, Furie BC, Tong MJ, Blanchard RA, Lo KJ, Lee SD, Coleman MS, Furie B. Des-gammacarboxy (abnormal) prothrombin as a serum marker of primary hepatocellular carcinoma. N Engl J Med. 1984; 310:1427-1431.

52. Volk ML, Hernandez JC, Su GL, Lok AS, Marrero JA. Risk factors for hepatocellular carcinoma may impair the performance of biomarkers: A comparison of AFP, DCP, and AFP-L3. Cancer Biomark. 2007; 3:79-87.

53. Beale G, Chattopadhyay D, Gray J, Stewart S, Hudson M, Day C, Trerotoli P, Giannelli G, Manas D, Reeves H. AFP, PIVKAII, GP3, SCCA-1 and follisatin as surveillance biomarkers for hepatocellular cancer in nonalcoholic and alcoholic fatty liver disease. BMC Cancer. 2008; 8:200.

54. Soga K, Watanabe T, Aikawa K, Toshima M, Shibasaki $\mathrm{K}$, Aoyagi Y. Serum des-gamma-carboxyprothrombin level by a modified enzyme immunoassay method in hepatocellular carcinoma: Clinical significance in small hepatocellular carcinoma. Hepatogastroenterology. 1998; 45:1737-1741.

55. Ikoma J, Kaito M, Ishihara T, Nakagawa N, Kamei A, Fujita N, Iwasa M, Tamaki S, Watanabe S, Adachi Y. Early diagnosis of hepatocellular carcinoma using a sensitive assay for serum desgamma-carboxy prothrombin: A prospective study. Hepatogastroenterology. 2002; 49:235-238.

56. Mita Y, Aoyagi Y, Yanagi M, Suda T, Suzuki Y, Asakura $\mathrm{H}$. The usefulness of determining des-gamma-carboxy prothrombin by sensitive enzyme immunoassay in the early diagnosis of patients with hepatocellular carcinoma. Cancer. 1998; 82:1643-1648.

57. Okuda H, Nakanishi T, Takatsu K, Saito A, Hayashi N, Watanabe K, Magario N, Yokoo T, Naraki T. Measurement of serum levels of des-gamma-carboxy prothrombin in patients with hepatocellular carcinoma by a revised enzyme immunoassay kit with increased sensitivity. Cancer. 1999; 85:812-818.

58. Cui R, He J, Zhang F, Wang B, Ding H, Shen H, Li $\mathrm{Y}$, Chen X. Diagnostic value of protein induced by vitamin $\mathrm{K}$ absence (PIVKAII) and hepatoma-specific band of serum gamma-glutamyl transferase (GGTII) as hepatocellular carcinoma markers complementary to alpha-fetoprotein. Br J Cancer. 2003; 88:1878-1882.

59. Tanaka Y, Kashiwagi T, Tsutsumi H, Nagasawa M, Toyama T, Ozaki S, Naito M, Ishibashi K, Azuma M. Sensitive measurement of serum abnormal prothrombin (PIVKA-II) as a marker of hepatocellular carcinoma. Hepatogastroenterology. 1999; 46:2464-2468.

60. Nakao A, Suzuki Y, Isshiki K, Kimura Y, Takeda S, Kishimoto W, Nonami T, Harada A, Takagi H. Clinical evaluation of plasma abnormal prothrombin (des-gamma-carboxy prothrombin) in hepatobiliary malignancies and other diseases. Am J Gastroenterol. 1991; 86:62-66.

61. Nomura F, Ishijima M, Kuwa K, Tanaka N, Nakai T, Ohnishi K. Serum des-gamma-carboxy prothrombin levels determined by a new generation of sensitive immunoassays in patients with small-sized hepatocellular carcinoma. Am J Gastroenterol. 1999; 94:650-654.

62. Wang CS, Lin CL, Lee HC, Chen KY, Chiang MF, Chen HS, Lin TJ, Liao LY. Usefulness of serum des-gammacarboxy prothrombin in detection of hepatocellular carcinoma. World J Gastroenterol. 2005; 11:6115-6119.

63. Kim do Y, Paik YH, Ahn SH, Youn YJ, Choi JW, Kim JK, Lee KS, Chon CY, Han KH. PIVKA-II is a useful tumor marker for recurrent hepatocellular carcinoma after surgical resection. Oncology. 2007; 72 Suppl 1:5257.

64. Lamerz R, Runge M, Stieber P, Meissner E. Use of serum PIVKA-II (DCP) determination for differentiation between benign and malignant liver diseases. Anticancer Res. 1999; 19:2489-2493.

65. Deyashiki Y, Nishioka Y, Takahashi K, Kosaka Y, Suzuki $\mathrm{K}$. Evaluation of des-gamma-carboxy prothrombin as a marker protein of hepatocellular carcinoma. Cancer. 1989; 64:2546-2551.

66. Cui R, Wang B, Ding H, Shen H, Li Y, Chen X. Usefulness of determining a protein induced by vitamin $\mathrm{K}$ absence in detection of hepatocellular carcinoma. Chin Med J (Engl). 2002; 115:42-45.

67. Sassa T, Kumada T, Nakano S, Uematsu T. Clinical utility of simultaneous measurement of serum highsensitivity des-gamma-carboxy prothrombin and Lens culinaris agglutinin A-reactive alpha-fetoprotein in patients with small hepatocellular carcinoma. Eur J Gastroenterol Hepatol. 1999; 11:1387-1392.

68. Tang W, Miki K, Kokudo N, Sugawara Y, Imamura H, Minagawa M, Yuan LW, Ohnishi S, Makuuchi M. Desgamma-carboxy prothrombin in cancer and non-cancer liver tissue of patients with hepatocellular carcinoma. Int J Oncol. 2003; 22:969-975.

69. Yuan LW, Tang W, Kokudo N, Sugawara Y, Karako H, Hasegawa K, Aoki T, Kyoden Y, Deli G, Li YG, Makuuchi M. Measurement of des-gamma-carboxy prothrombin levels in cancer and non-cancer tissue in patients with hepatocellular carcinoma. Oncol Rep. 2004; 12:269-273.

70. Tang W, Kokudo N, Sugawara Y, Guo Q, Imamura H, Sano K, Karako H, Qu X, Nakata M, Makuuchi M. Desgamma-carboxyprothrombin expression in cancer and/ or non-cancer liver tissues: association with survival of patients with resectable hepatocellular carcinoma. Oncol Rep. 2005; 13:25-30.

71. Inagaki Y, Tang W, Makuuchi M, Hasegawa K, Sugawara Y, Kokudo N. Clinical and molecular insights into the hepatocellular carcinoma tumour marker desgamma-carboxyprothrombin. Liver Int. 2011; 31:22-35.

72. Inagaki Y, Xu HL, Hasegawa K, Aoki T, Beck Y, Sugawara Y, Tang W, Kokudo N. Des-gammacarboxyprothrombin in patients with hepatocellular carcinoma and liver cirrhosis. J Dig Dis. 2011; 12:481488.

73. Inagaki Y, Qi F, Gao J, Qu X, Hasegawa K, Sugawara Y, Tang W, Kokudo N. Effect of c-Met inhibitor SU11274 on hepatocellular carcinoma cell growth. Biosci Trends. 2011; 5:52-56.

74. Gao JJ, Inagaki Y, Xue X, Qu XJ, Tang W. c-Met: A 
potential therapeutic target for hepatocellular carcinoma. Drug Discov Ther. 2011; 5:2-11

75. Song PP, Gao JJ, Kokudo N, Dong JH, Tang W. "Knowledge into action" Exploration of an appropriate approach for constructing evidence-based clinical practice guidelines for hepatocellular carcinoma. Biosci Trends. 2012; 6:147-152.

76. Shen Q, Fan J, Yang XR, et al. Serum DKK1 as a protein biomarker for the diagnosis of hepatocellular carcinoma: A large-scale, multicentre study. Lancet Oncol. 2012; 13:817-826.

77. Peter A, Prieto, Charles H, Cha. DKK1 as a serum biomarker for hepatocellular carcinoma. Hepatobiliary Surg Nutr. 2013; 2:127-128.

78. Zhu WW, Guo JJ, Guo L, et al. Evaluation of Midkine as a Diagnostic Serum Biomarker in Hepatocellular Carcinoma. Clin Cancer Res. 2013; 19:3944-3954.

79. Pepe MS, Etzioni R, Feng Z, Potter JD, Thompson ML, Thornquist M, Winget M, Yasui Y. Phases of biomarker development for early detection of cancer. J Natl Cancer Inst. 2001; 93:1054-1061.

(Received April 3, 2014; Revised May 26, 2014; Accepted May 31, 2014) 